\title{
More older patients are stuck in hospitals
}

\author{
David Oliver, consultant in geriatrics and acute general medicine
}

Berkshire

The UK National Audit Office (NAO) has just published the report Discharging Older Patients from Hospital. ${ }^{1}$

It focuses on the growing number of older people who are technically fit enough to leave acute hospitals in England but remain stranded. Why? Because the community services they need to support them out of hospital lack the funding, capacity, or quick response times to match their need. Such cases are officially reported as "delayed transfers of care" (DTOC).

These delays are rapidly worsening and have reached record levels. ${ }^{2}$ The NAO found that bed days due to DTOC rose by $31 \%$ from 2013 to 2015 alone. We now have 1.15 million bed days a year officially reported as caused by DTOC in English hospitals- $85 \%$ concerning patients over 65 . Meanwhile, emergency admissions in over $65 \mathrm{~s}$ have risen by $18 \%$ since $2010-11$, and the percentage of people over 65 is projected to rise rapidly. ${ }^{1}$

Despite this demography, social care has seen sustained funding cuts since 2010. ${ }^{3}$ The NAO found that waits in hospital for home care have doubled since then, and waits for care homes increased by $63 \%$. Neither the government's Better Care Fund nor the new Social Care Precept, by which local councils can raise an extra $2 \%$ on council tax, can reverse the funding gap. ${ }^{4}$

Delays in community health services are also rising. Average waits from referral for home based intermediate care "reablement" and rehabilitation have risen steeply, to six and eight days, respectively. ${ }^{5}$ Commissioners can take weeks to make decisions about funding NHS continuing care, often with patients marooned in hospital while we argue over money. ${ }^{6}$

Practitioners on the wards have long known that official DTOC figures were overly optimistic. The NAO agrees, estimating the real number of bed days related to delays to be 2.7 times higher. It also estimated that such delays cost about $£ 880 \mathrm{~m}(€ 1140 \mathrm{~m}$; $\$ 1270 \mathrm{~m}$ ) a year. Its best case hypothetical estimate for supporting all of those bed days outside hospital was only $£ 180 \mathrm{~m}$.

But keeping emptied wards closed is hard when hospitals are already full; hence, modelled savings are hard to realise. ${ }^{7}$ And now acute hospitals are told to find a highly improbable $£ 8.7 \mathrm{bn}$ of the $£ 22$ bn NHS "efficiency savings" by $2020 .{ }^{8}$ Only $5 \%$ of all acute admissions in over $65 \mathrm{~s}$ are longer than 21 days, but they now account for over $40 \%$ of all bed days. ${ }^{6}$

Hospital clinicians face a daily "hurry up and wait" ritual of chasing and challenging staff in community services or families exercising choice for self funded care, and of apologising to patients and carers for delays we don't control and that we struggle to influence.

It's demoralising for us. For patients, it's often bewildering and soul destroying. ${ }^{9}$

Pull quote -- Hospital clinicians face a daily "hurry up and wait" ritual of chasing and challenging staff in community services for delays we don't control and that we struggle to influence

Competing interests: See www.bmj.com/about-bmj/freelancecontributors/david-oliver.

Provenance and peer review: Commissioned; not externally peer reviewed.

1 National Audit Office. Discharging older patients from hospital. 26 May 2016. https://www. nao.org.uk/.

2 Thompson J. Delayed transfers of care: join the queue. King's Fund blog. 9 Nov 2015. www.kingsfund.org.uk/blog/2015/11/delayed-transfers-care-join-queue.

3 King's Fund. Social care budget cuts damaging the NHS, latest quarterly monitoring report finds. 22 Oct 2015. www.kingsfund.org.uk/press/press-releases/social-care-budget-cutsdamaging-nhs-latest-quarterly-monitoring-report-finds.

4 Humphries R. Where does the spending review leave social care? Health Serv J 2015 Dec 14. www.hsj.co.uk/topics/spending-review-2015/where-does-the-spending-reviewleave-social-care/7001005.article.

5 NHS Benchmarking. National audit of intermediate care: summary. Nov 2015. www. nhsbenchmarking.nhs.uk/CubeCore/.uploads/NAIC/Reports/ NAICReport2015FINALA4printableversion.pdf.

6 NHS Benchmarking. Older people in acute care settings: benchmarking report. Apr 2015. www.nhsbenchmarking.nhs.uk/CubeCore/.uploads/Older\%20Peoples/ NHSBNOPReport2014Circ.pdf.

7 NHS Confederation. Dealing with the downturn—using the evidence. 18 Jun 2010. www. nhsconfed.org/resources/2010/06/dealing-with-the-downturn-using-the-evidence.

8 House of Commons Committee of Public Accounts. Sustainability and financial performance of acute hospital trusts: 30th report of session 2015-16. 7 Mar 2016. www. publications.parliament.uk/pa/cm201516/cmselect/cmpubacc/709/709.pdf.

9 Healthwatch England. Special inquiry: Safely home: what happens when people leave hospital and care settings? Jul 2015. www.healthwatch.co.uk/sites/healthwatch.co.uk/ files/170715_healthwatch_special_inquiry_2015_1.pdf.

Published by the BMJ Publishing Group Limited. For permission to use (where not already granted under a licence) please go to http://group.bmj.com/group/rights-licensing/ permissions 